\title{
The Politics of Faith in the Work of Lorna Dee Cervantes, Ana Castillo, and Sandra Cisneros
}

\section{Darlene Pagan \\ Pacific University}

If Chicanas are perceived as a communal threat because they are closer to the carnal, according to the Church, they paradoxically are worshipped as the female divine within indigenous practices like Yoruba or Mexica as well. In the works of Sandra Cisneros, Ana Castillo, and Lorna Dee Cervantes women's religious commitment is revealed through their possible responses to cultural multiplicity: 1) the rejection of one tradition over another, 2) syncretism, or 3) the continual migration between practices despite contradictory impulses. Using irony to address the tension and seeming impossibility of maintaining distinct traditions simultaneously, these writers intimate how women derive strength and a stronger sense of self primarily by moving between traditions.

Used as a term to identify a population, Chicano/a embodies a multiplicity of cultures-Indian, Anglo, Mexican, Spanishand the history associated with them. For some Mexicans born in the United States, Chicano/a is a preferred term because, unlike the terms Mexican American, Hispanic, or Latino/a, it includes cultural plurality and a sense of the strife and struggles 


\section{Ethnic Studies Review Volume 26: 1}

marked by the social and political upheaval of the 1960s, the history of which reaches back to 1848 when the Treaty of Guadalupe shifted the U.S./Mexican border further south. Although little in their daily lives immediately changed, the border shift opened the way for a unique community of American citizens whose language, heritage, beliefs, and practices drew from multiple cultural communities. In some cases the points of contact meant wholly new entities, as in the case of language, where new dialects arose like Pachuco Spanish or Spanglish, or in the case of religion, where multiple practices and beliefs gave rise to traditions like the Day of the Dead or the cult of the Virgin Mary, both of which combine indigenous and Catholic practices.

In the case of the latter religion continues to be a contested point of contact for the Chicanos/as, and recent critical attention has focused on more widely known traditions like the cult of the Virgin and its affects on communities in Mexico and the U.S. But how can Catholicism, which has been identified as a colonizing force by the Spanish Conquistadors, absorb traditions and practices that reflect radically different perspectives about forms of worship and men and women? As Bettina Aptheker notes, for example, at the heart of colonization is a "belief in the superiority of men; in the superiority of male judgment and authority; and in the absolute priority given to achieving male approval and validation" (135-36). This perspective is juxtaposed to many indigenous traditions and rituals, such as Mexica or Yoruban, that derived guidance from goddess worship or the belief that spirits of the dead are accessible on earth.

Of primary importance in the present discussion is how the supplanting of religious practices and beliefs meant particular changes for women, their roles, and their perceived roles. How do women fare, for example, when confronted by traditions and practices that alternately worship and denigrate them? According to Gloria Anzaldúa, women especially suffer under the Church because it insists that women are "carnal, animal, and closer to the undivine" (17), which means that they must be protected by the Church and by men; however, this protection is more often translated as subservience when women are expected to conform to rigid gender roles (17). If women risk their salvation simply by being women, then they especially must com- 
mit themselves to the values of their culture, including those of the Church. Thus the situation for Chicanas in light of the tensions between different cultural practices has serious implications for their daily lives in terms of their freedom, strength, and power as women. My concerns are with how these tensions are attended to in the poetry of three writers who identify themselves as Chicana: Lorna Dee Cervantes, Ana Castillo, and Sandra Cisneros. In these writers' works women's religious commitment is revealed through their possible responses to cultural multiplicity: 1) the rejection of one tradition or practice over another, 2) syncretism, which combines or blends the practices of one or more traditions, and 3) the continual migration between practices despite contradictory impulses and situations. Little discussion has occurred on the last point that concerns not only a migration between practices and traditions but between cultures. ${ }^{1}$ These writers intimate how women derive strength and a stronger sense of self when they move between traditions rather than considering them separate or melded. At the same time irony does not escape these writers as a tool to address the sheer tension and seeming impossibility of maintaining such distinct traditions simultaneously.

In the work of Cisneros the notion of faith is more often a primary subject in her fiction though her poetry offers a concise engagement with the notion of faith as tied to characters' sense of self as women. Cisneros uses irony especially to reveal that she does not accept Catholic doctrine that relegates the body to the carnal and animal, thus to the base and vile. In her poetry faith is aligned not only with the body but with sexuality specifically. Sexuality, love, and intimacy are discussed in the language of faith in terms that are both ecstatic and blasphemous. Cisneros' poem, "Christ You Delight Me," includes a direct address to Christ that also plays on a blasphemous colloquial expression that might be directed to anyone. In this poem, the cultural migration that occurs is between traditions of faith that use the body as a site of both worship and denial. The religious terminology is used to describe the sexual body: "Christ you delight me, / Woolen scent of your sex, / ...Blessed resurrection of thigh" (25). The language is on one hand blasphemous in a Catholic context, and yet it has been adopted to worship the 


\section{Ethnic Studies Review Volume 26: 1}

body in a literal sense. There is more than the enjoyment of sexuality at work here, as the return of the body to its place as sacred, particularly as it is connected to the earth and to traditions where the earth, another body, is also sacred and something to be worshipped. At the end of the poem the narrator squats over the earth, her "little pendulum...Ringing, ringing, ringing" (25). Like the tolling of a bell that signals gathering parishioners, the narrator's bell is her sex, inviting and tolling the earth's body. The reclamation of the body as both earthly and sacred is extraordinary considering that Catholicism itself has been marked historically by an abnegation of the body, particularly its pleasures. Yet in "Christ You Delight Me" Cisneros not only invokes the body of Christ in a playful manner, exploding the traditional emphasis on his physical suffering, but she also invokes his name as slang, questioning the religious authority that fails to recognize the sex and sexuality of women.

In Cisneros" "Something Like Rivers Ran" a couple's physical intimacy turns them into not one but many religious figures to de-legitimize the authority of a single practice of faith and thus of a singular view of sex and sexuality. The couple's sexual union culminates in their emerging from multiple traditions: "and we were Buddha / and we were Jesus / and we were Allah / at once / a Ganges absolving / language woman man" (20). While the scenario might suggest that through sexuality the narrator becomes God, this is not the case; their union maintains the sacredness of the various religious and spiritual traditions and removes the language that separates them both physically and spiritually, maintaining the truth and sacredness of each tradition and thus of each person. Each tradition is separate and fraught with language that distinguishes and separates it from others, but beneath both is a sense of the sacred, an awe for what is above, beyond, and outside of the body. The running of the rivers, particularly one that is holy, dissolves the differences that separate one body from another while at the same time recognizing them one by one. The sexual act may be considered sacred or adulterated, depending on any given context, but Cisneros removes that dichotomy to insist on the inherent sacredness of the body and sexuality in a context of faith.

"Love Poem for a Non-Believer" through its title directly 
connects notions of love to faith using the absence of faith to do so. This absence has a direct set of consequences in terms of how the two characters engage their bodies. Outside of any context of faith their relationship is one that verges on violence. The poetry rejects metaphor and symbol, using language that is direct and straightforward, with the narrator articulating in specific terms what her lover enjoys about her body and thus what she touches now that he is absent. She imagines his hands over hers, but soon recognizes what he might be capable of: "My neck is thin / You could cup / it with one hand / Yank the life from me / if you wanted" (29). The absence of faith in any cultural sense leaves the intimacy between them open to the possibility of violence; the narrator is somehow more vulnerable because of his lack of faith. She is at his mercy because there are no guiding force or moral underpinnings from which she can assume either his motivations or behavior when he physically lays his hands on her. No specific system is named, but the abstract sense of a "non-believer" indicates less that a particular system is warranted than that some system is required in this situation; by the end of the poem the couple cannot hear the "prayer call / of a Mohammed" because they have no word for it but religion. Religion is understood as an abstract construct, a system they know formally but not in body or soul, which removes it from any sense of the sacred or the physical. The sounds, like the words and traditions and practices they stand for, are empty.

While critics articulate the movement between religious traditions as syncretic or ambiguous, as do Gloria Anzaldúa and Carmen Aguinaco, for example, the above portrayals of faith as tied to the body seem anything but entirely syncretic or ambiguous. The Chicana or mestiza's experience is certainly multi-layered but these layers seem to me to function more like an onion, each layer whole and necessary even if not directly visible. In her essay, "Guadalupe the Sex Goddess," Cisneros returns the Virgin to her original incarnation before the conquest, the Nahuatl deity, Tonantzin, to articulate her desire and her capacity for reproduction as it reflects women's perspectives and not those of the church. Thus Cisneros reincarnates the body and sexuality into the sacred without diminishing the individual contexts where women or the sacred appear. Depending on the 


\section{Ethnic Studies Review Volume 26: 1}

poetic context, Cisneros' work migrates between traditions and practices that leaves each whole but allows her to engage and also to interrogate each.

Though akin to Cisneros' work, which identifies the feminine with the sacred, Castillo is in some ways more direct about the specific traditions of faith that her poems engage and how. The loss of indigenous traditions is one of the primary focal points of her work and in her poem, "Ixtacihuatl Died in Vain," the author names the site and articulates reasons for the loss keeping a tradition alive through her very words. In the poem the women are connected to what is deemed folklore and mythology, while the men are more closely associated with the sacred and the blessedness associated with traditional Catholicism. Women, she asserts, are Ixtacihuatl, the "sleeping, snowcapped volcanoes / buried alive in myths / princesses with the name of a warrior / on our lips" (39). The story she refers to is about the twin volcanoes in Mexico, who were once warrior and princess but who die together in a Romeo and Juliet fashion (41). When the male volcano speaks, he accuses his bride of loving too vastly and wide and denies that she was his bride at the wedding where their mothers and fathers were not invited. He identifies the fathers here as "the fourteen / stations of the cross" (39). The stations of the cross indicate uninvited wedding guests but men specifically who are partially responsible for the death of Ixtacihuatl in the same way that they might have been responsible for the death of Christ. As if to sacrifice her son in the religious tradition of the fathers, Ixtacihautl offers up her son's "palpitating heart" so that his father might replenish himself (39). Ixtacihautl forgives him for the act, and in the end when she says, "the tremor of a lie" is in even the "greatest truths" (41), she suggests that the traditions of faith work under both truth and lies, and that, as a result, both life and death result. Ixtacihuatl's death is marked, for example, "in the book of myths / sum of our existence" (40), as if to say that one faith is now simply considered a myth by some in favor of another faith marked by stations, rigidity, and held in place by the station of men, that might one day also be considered myth. Ixtacihuatl wants to place the myths and legends beside other traditions, not supplanting one with another and perhaps suggesting that all myths are based on 
a truth. She wants both recognized for what they espouse, for good and ill. If only the supplanting of tradition occurs, death is inevitable, not only of tradition in general but of the existence and subsistence of a cultural past, particularly women's.

While there is on one hand a faith in Catholicism there is simultaneously a sense of loss in Castillo's poetry based on cultural context, but it is not a loss of a tradition per se. In "Guadalupe" the narrator addresses the Virgin in Spanish like a friend, and in fact the poem is dedicated to Lupe Gárnica at the end, which invokes both the Virgin as sacred figure and Guadalupe as friend in flesh and blood. In the poem the narrator insists that Guadalupe will fail her despite being she whose "vela que nunca se apaga / ...poderosa y llena [whose candle is never extinguished...powerful and full]" (53). ${ }^{2}$ If Guadalupe fails her, the source of that failure seems to be her new cultural context in the New York City streets where her figure's esteem as a sacred icon is diminished; she walks the streets followed by a line of cats, dogs, and children (53). The narrator says that she does not call Guadalupe "Mamá," this woman who is no saint, but that ultimately "cuando Ilamen / tu nombre: yo respondaré [when they call / your name: I will respond]" (53). The narrator will be the one to recognize the Virgin so far from their homeland, so far from "el otro lado / de la luna [the other side of the moon]" (53), even if others see her as any woman in a crowd. The survival both of self and tradition in "Guadalupe" is dependent in part on the context in which she appears and what is needed by the faithful in that context, but the survival of Guadalupe as a woman and icon, and the spiritual guidance she represents is not.

In "In My Country" the narrator refers to the homeland that she is far from and asserts that in her original country, "there is no god / crucified to explain / the persistence of cruelty" (88), though ironically, one of the ways Catholicism became so entrenched in the community was through an allegiance to Christ based on suffering as a shared experience from which there was relief only through faith. At the same time the country to which the narrator refers is one that appears to combine the best of all worlds and condemn the worst; in fact, the country in which there is no need for a Christ like the one named is the 
same one in which the traditions that do survive are those based in love, charity, and celebration. In an assertion of ancient practices, the narrator explains: "In my world, Mesoamerica / was a magnificent Quetzal, / Africa and its inhabitants / were left alone. Arab women / don't cover their faces or / allow their sexual parts to be / torn out. In my world, / no one is prey" (90). The world is both imagined and real in that it represents real possibilities. Here is not only the plight of Mexicans but also of any who suffer cultural and religious conquest or persecution. At the end the narrator, in speaking all languages, speaks all traditions, particularly those that do not ground either the body or its experiences in suffering. Only in a Christian context is there relief from suffering through death alone, though her point is not to denigrate the worst aspects of traditions of faith solely but to disparage the persecution of people in all its guises.

Castillo's work urges a larger conversation concerning religion and its effects on daily life and the wider net needed to encompass multiple traditions. At the same time Castillo is concerned with reclaiming women's sexuality in positive and selfaffirming ways, both as related to issues of faith and in its own right. Her poetry and critical work attest to her concerns about the ways, for example, that Catholicism teaches women to be ashamed of their bodies and their sexuality because of women's "relation to Evil Eve" (Massacre 122). Indeed, the sexual woman is the "woman begging rape, begging vulnerability to society, begging to be treated as nothing more than as what she was born: a female who merits no respect for her emotions, her mind, her person" (123). Castillo eschews any culture-Anglo, Arab, Mexican, or otherwise-that asks young women to deny their own sexuality if they are to avoid the "punitive taboos surrounding the female" (124). The solution is not to further deny by eschewing faith or religion in general but by claiming and reclaiming; only Chicanas themselves can begin to explore what this means for their "erotic selves" and what it means also to "remain true to the Mexican/Chicana/Latina/India/mestiza aspects of our sociopolitical identity" (141). Every woman must decide how to negotiate her sexual self and space, beginning with acceptance and understanding.

Choice in many of the poems we have been exploring is 
often what multiplicity and plurality imply. Lorna Dee Cervantes' work is no exception, and in her poems in particular, the theme of migration that choice allows is a frequent controlling metaphor. "Beneath the Shadow of the Freeway" articulates the narrator's perceptions of faith as analogous to the traditions of women in her life, specifically her mother and grandmother, all three women representing differing spiritual traditions resulting from the connections each feels to a particular or to multiple culture(s). The narrator uses the language of fairy tales to narrate these traditions and indicate how her own traditions derive from these and from the added arena of the language of books connected directly to an American education that neither her mother nor her grandmother had. The narrator's mother is tied to the life of the freeway and to America and is identified as "the Swift Knight, Fearless Warrior" who "wanted to be Princess instead," and who hardens as a result primarily against the men with whom she has had a series of negative relationships (11). The mother's advice to her daughter is not to count on anyone, otherwise: "You'll get nothing but shit" (13). On the other hand, the grandmother is an "innocent Queen" who attempts to live by the old traditions in the new world of California and who remained "with a man who tried to kill her" (12). The grandmother "believes in myths and birds. / She trusts only what she builds / with her own hands" (12). Her innocence derives from her inability, or refusal, to live outside of old traditions, wherein she reads birds to tell the weather, seemingly blind to the freeway shadow that represents progress and America.

While the mother seems to have rejected the old to adapt to the new culture, relying on cynicism to make her way in the world, the grandmother clings to the old, relying on her faith in her hands, birds, and myths, seemingly oblivious to the fact that she is in a new world. Both the mother and grandmother adhere to traditions and beliefs that prove both useful and damaging. They make their way in the world, but for the mother, the cost is her being alone and, for the grandmother, the cost was a continual threat to her life by her husband because it was tradition to remain married. The narrator, caught between what her mother and grandmother represent, turns to books, becoming the family "Scribe: Translator of Foreign Mail, / interpreting letters from the 


\section{Ethnic Studies Review Volume 26: 1}

government, notices / of dissolved marriages and Welfare stipulations. / I paid the bills, did light man-work, fixed faucets, / insured everything / against all leaks" (11). By insuring against leaks, the narrator does what is traditionally a man's work in the home, though she neither rejects men entirely nor assumes that she is not whole without a husband; rather, she adopts her mother's faith in herself and her grandmother's faith in something larger than herself, something outside of male/female relations. As scribe the narrator has the added benefit of being able to (re)write her definitions of self and inhabit the role of creator and storyteller in which she is the central character.

One of the most important relationships for the narrator in Cervantes' collection is not solely with a mother or grandmother but with a near mythic character she calls Caribou Girl. In the lengthy poem of the same name, the narrator is in awe of this girl to whom crows speak and send poems, who speaks "her own mythology, her own sanity" (21). Caribou Girl is perceived by unnamed others in the world as "too strange" but also as beautiful, in part because she is the one who seems able to inhabit the space of cultural plurality safely and comfortably. Not only does she communicate with crows, she relies on the language and tradition of the Plains tribes by asserting that the "Wankan Tanka is nothing / but the mockingbird" (21). ${ }^{3}$ She then invokes two Aztec and one Native American god-figure: "Quetzalcoátle, Ometeótl, the Great Manitou" (22); the first two gods derive from Aztec civilizations, also called Mexica, and refer to the PreciousFeather Snake and the god of duality (time and space, female and male, spirit and material), respectively. ${ }^{4}$ Caribou Girl's successful metaphoric flight through life is in part because everything and all traditions for her are sacred. In the suggestion that the Wakan Tanka is the mockingbird, for example, Caribou Girl recognizes that a translation occurs between cultures that apply separate names to similar god-figures. What is called the Wakan Tanka or Quetzalcoátle in one culture might be called the mockingbird or the Great Manitou in another. The figures are not equivalents but rather translations of distinct figures with shared features that Caribou Girl can call on as she sees fit, as she needs to. Caribou Girl recognizes the strength to be derived from multiplicity and learns "the serenity / of a mockingbird, the justice / 
of a crow, blue jay's strength; / I've dipped their feathers in blood / to seal the pact-my path" (22). She belongs to all traditions as they belong to her.

Caribou Girl's path is to walk the fine line between cultural traditions, just as the narrator does earlier in the poem, and thereby recognize multiple versions of faith that are not as radically different as they may appear on the surface though they are distinct. However comfortable Caribou Girl is as cultural translator, the narrator perceives this position as possible through "little tricks of the sane . . . the balance of hooves / and the wade through ice" because she has not yet defined her faith according to the multiple cultures within which she too participates (22), though she wants to. The use of irony to articulate faith returns, not in terms of the existence of contradictory practices but in their dangerous balance. While the narrator believes that the Caribou Girl "will drown" in her dizzying dance over water among divergent traditions, the poem's concluding image is ironically of the narrator drowning in Caribou Girl's world. The narrator says that she must "leave her [Caribou Girl] / for another breath / before I plunge / with her again" (23). The metaphoric plunge is not into water but into the world of Caribou Girl, which the narrator can visit but to which she does not belong. The narrator yet has to negotiate fully the slippery and seemingly "insane" terrain in which such divergent traditions might coexist comfortably, but she is provided an example of how to successfully do this through Caribou Girl. In the same breath that she believes the terrain impossible, she finds herself inside of it.

The Caribou Girl represents multiple cultural traditions that are a threat to both the dominant culture and to the narrator, though for entirely different reasons. While Caribou Girl knows the books of the dominant culture, she represents a threat to it because she participates in religious traditions historically identified as pagan by Anglos and non-whites. That Caribou Girl might drown in a contemporary setting suggests that there might be little room for the kind of faith she practices in a world where boundaries are sharply drawn. The narrator also fears Caribou Girl because the narrator has not been able to do what Caribou Girl has done, which is to successfully negotiate multiple cultural traditions and use them as she sees fit. The narrator is well 


\section{Ethnic Studies Review Volume 26: 1}

aware of the contradictions between these traditions.

The narrator in Cervantes' collection is the same throughout, and her journey in the poems is one of negotiating her sense of self. As the narrator moves physically and metaphorically between north and south, between the United States and Mexico, she negotiates the cultural and spiritual traditions of each locale, often as it is passed down through the hands of women. The narrator gains greater wisdom and understanding regarding her role and connection to her culture and to the traditions espoused by her ancestors. More important, the characters around her, whether family or friends, provide examples of the options from which the narrator can choose, and by extension, readers are provided with just as many examples and options for how women occupy cultural roles and spaces.

Migrating between cultural traditions is no easy feat. The terrain is often uncertain and dangerous, as these poems indicate, but negotiation is both possible and useful. For women especially, at stake is not only cultural subjectivity but the embodied experiences of women who must negotiate the kinds of roles they can or will inhabit given the divergent expectations of their culture and their church. Syncretism is certainly one of the options and all three of these writers in some form or another intimate that practice in their work; clearly, the very notion of folk Catholicism as expressed or experienced by MexicanAmericans, Latinos, or Chicanos/as suggests how a tradition can absorb and adapt to include new ideas and practices and still remain a single tradition. But there is yet another option that these three authors offer that is especially relevant for women who are ironically both denigrated by certain religious ideology because of their perceived carnal nature and also celebrated for many of the same aspects. Cervantes, for example, points to this irony through the experience of menstruation that, in some cultures, signals women's power, and yet, "civilized society would call the blood that creates life a curse" (124). In accepting and embracing particular traditions, the emphasis is on the migration between as opposed to the casting off or diluting of one in favor of another; to denigrate syncretic practices works against the notion of choice and migration that is key to cultural and selfaffirmation. Migration emphasizes movement that maintains life 
as opposed to stasis. And as the ones to give life in the literal or the creative sense, women especially are in a position to reclaim without sacrificing self or other.

\section{WORKS CITED}

Aguinaco, Carmen "Creative Tension: How Latina Writers Make Sense of Two Worlds." U.S. Catholic. 64.11 (November 1991): 34-5.

Anzaldúa, Gloria. Borderlands/La Frontera: The New Mestiza. San Francisco: Spinsters/Aunt Lute, 1987. 17.

Aptheker, Bettina. Tapestries of Life: Women's Work, Women's Consciousness, and the Meaning of Daily Experience. Amherst: $U$ of Massachusetts $\mathrm{P}, 1989$. 135-36.

Castillo, Ana. Massacre of the Dreamers: Essays on Xicanisma. New York: A Plume Book, 1994. 122-23.

-----. My Father Was a Toltec and Selected Poems. New York: W.W. Norton \& Company, 1995.

Cervantes, Lorna Dee. Emplumada. Pittsburgh: U of Pittsburgh P, 1981.

Cisneros, Sandra. "Guadalupe the Sex Goddess." Ms. 7.1 (1996): 4348.

----. Loose Woman. New York: Vintage Books, 1994.

León, Luis D. "Metaphor and Place: The U.S.-Mexico Border as Center and Periphery in the Interpretation of Religion." Journal of the American Academy of Religion 67.3 (?): 541-71.

\section{NOTES}

1 I am grateful to Juan Bruce-Novoa, whose work with Puerto Rican writer Judith Ortiz Cofer inspired my use of the term migration-as taking place between the mainland and the island-in this distinct context. See "Judith Ortiz Cofer's Rituals of Movement." The Americas Review. 19.3-4 (Winter 1991): 88-89.

2 All translations of this poem are my own.

3 See Allen, Paula Gunn. The Sacred Hoop: Recovering the Feminine 


\section{Ethnic Studies Review Volume 26: 1}

in American Indian Traditions. Boston: Beacon Press, 1986. 61-2.

4 Pérez-Torres, Rafael. Christine Garcia's The Aguero Sisters and Julia Alvarez's How the Garcia Girls Lost Their Accents are novels that revolve around the conflicts and tensions among the members of the two immigrant families, the Aguero sisters from Cuba and the Garcia sisters from the Dominican Republic, arising mainly from their need to come to terms with their ambiguous identities. This article focuses on the ways in which the Aguero and Garcia sisters through their hybrid identities overcome boundaries and exclusive categories so as to challenge homogenizing, hegemonic systems, and open vistas into new, non-essentialist modes of identity that still can be represented in their specific configurations.. Santa Barbara: $U$ of California P, 1995. 17981. 